\title{
The emplacement of pahoehoe lavas on Kilauea and in the Deccan Traps
}

\author{
H C SHETH \\ Department of Earth Sciences, Indian Institute of Technology (IIT) Bombay, \\ Powai, Mumbai 400 076, India. \\ e-mail: hcsheth@iitb.ac.in
}

There is a growing interest in deciphering the emplacement and environmental impact of flood basalt provinces such as the Deccan, India. Observations of active volcanism lead to meaningful interpretations of now-extinct volcanic systems. Here, I illustrate and discuss the morphology and emplacement of the modern and active lava flows of Kilauea volcano in Hawaii, and based on them, interpret the compound pahoehoe lavas of the Deccan Traps. The latter are vastly larger (areally extensive and voluminous) than Kilauea flows, and yet, their internal architecture is the same as that of Kilauea flows, and even the sizes of individual flow units often identical. Many or most compound flows of the Deccan Traps were emplaced in a gentle, effusive, Kilauea-like fashion. Bulk eruption rates for the Deccan province are unknown, and were probably high, but the local eruption rates of the compound flows were no larger than Kilauea's. Large $\left(\geq 1000 \mathrm{~km}^{3}\right)$ individual compound pahoehoe flows in the Deccan could have been emplaced at Kilauea-like local eruption rates $\left(1 \mathrm{~m}^{3} / \mathrm{sec}\right.$ per metre length of fissure) in a decade or less, given fissures of sufficient length (tens of kilometres), now exposed as dyke swarms in the province.

\section{Introduction}

The emplacement and environmental impact of flood basalt eruptions have been topics of much interest and debate in recent years (see e.g., Self et al 1997; Bondre et al 2004a, b and references therein; Wignall 2005). Several flood basalt episodes in Earth history have overlapped with major mass extinctions, and may even have been their cause, though several other flood basalt episodes were not associated with mass extinctions (Wignall 2005; Kerr 2005). The celebrated Deccan flood basalts of India overlapped with the major Cretaceous/Tertiary Boundary mass extinctions $\sim 65$ million years (m.y.) ago (e.g., McLean 1985). The ambiguity in relating specific flood basalts to particular mass extinctions is due to geochronological data that are insufficiently precise to establish exact temporal coincidence (Baksi 2001), inadequate morphological characterization of many old flood basalts, and insufficient knowledge of their emplacement mechanisms and pre-eruptive volatile contents.

Here, I discuss the morphology and emplacement mechanisms of the compound pahoehoe lavas of the Deccan Traps - one of the major flood basalt provinces of the world - and draw exact parallels with recent and active lava flows of the Kilauea volcano in Hawaii - the world's most active and intensely studied volcano. This paper is not intended to provide elaborate discussions of the morphological features and emplacement of the Deccan lavas, which appear in recent exhaustive overviews (Bondre et al 2004a, b). This paper also does not attempt an overview of the morphology of lava flows and volcanic systems in general, for which the reader is referred to a nicely illustrated website managed by Vic Camp, located at www.geology.sdsu.edu/how_volcanoes_work. Here, I offer field data on the morphology and

Keywords. Volcanism; lava; Kilauea; Hawaii; Deccan; flood basalt. 


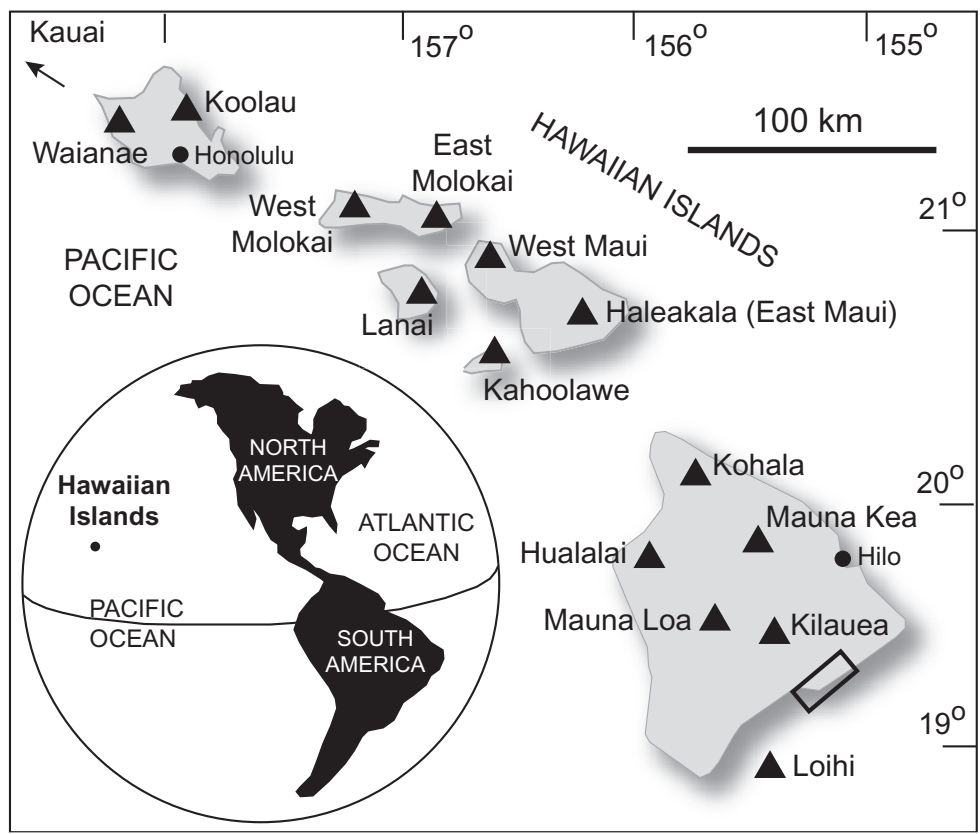

Figure 1. Simplified map of the Hawaiian islands. Dark triangles are the major volcanoes, of which Kilauea, Mauna Loa and Loihi seamount (below sea level) are currently active. Based on Frey and Rhodes (1993). Rectangular box over Kilauea shows the area of current and recent volcanic activity, from where the photographs in figures 2 to 4 come.

emplacement of the Kilauea and the Deccan compound flows, based on first-hand observations in both provinces. I then discuss the significance of the data in understanding the eruption rates of the Deccan lavas, note some prevailing misconceptions in Deccan volcanology, and end with some comments and thoughts on the likely environmental impact of the extensive and voluminous Deccan compound lava flows. I begin with a brief description of Kilauea's lava flows.

\section{Kilauea and its active lava flows}

Observations of active volcanism are invaluable, as these allow meaningful interpretations to be made of now-extinct volcanic systems. Active volcanoes of the islands of Hawaii in the Pacific Ocean (figure 1) have been very important to the development of volcanology and igneous petrology. These islands are merely the exposed tops of huge shield volcanoes which rise some $10 \mathrm{~km}$ from the ocean floor and yet have gentle gradients. The geology of the Hawaiian islands is only too well known from scores of technical and popular works (e.g., Macdonald et al 1983; Hazlett and Hyndman 1996; TenBruggencate 2000; Decker and Decker 2001; Sheth 2003), and I will merely present a very basic (and perhaps oversimplified) introduction which will, nevertheless, help the reader understand the arguments advanced in a later section for the Deccan lavas. Apart from the submarine volcano Loihi at the southeastern end of the Hawaiian island chain, the two active shield volcanoes situated on the 'Big Island' of Hawaii are Mauna Loa (rising $4166 \mathrm{~m}$ above sea level, last eruption in 1984) and Kilauea (1248 $\mathrm{m}$ above sea level, last eruption ongoing since 1983; see the website of the Hawaiian Volcano Observatory, U. S. Geological Survey, at http://hvo.wr.usgs.gov). Kilauea is the most active and most 'safe' volcano on Earth that almost always emits fluid lava and has rarely had explosive ash eruptions during the last few centuries. A presently active vent on Kilauea is a cone known as Pu'u' O'o'. After erupting from the crater at the top of the cone, the lava flows downslope and towards the ocean. The lava mixing with seawater immediately quenches and shatters and makes new land and this is how these volcanic islands grow.

Some of the lava, after coming out of the vent, moves in open channels, where it is exposed to the atmosphere. It therefore quickly loses heat and becomes highly viscous, rough, and clinkery. Such lava is known by the Hawaiian name $a a$. Open lava channels can also develop solid roofs by cooling, and the remaining lava moves underground in a lava tube. Lava flowing in a tube is not visible, except through openings (skylights) in the solid roof of the tube. Surface breakouts from the roofs of lava tubes bring lava out on the surface (figure 2). Breakouts happen as the lava is progressing internally towards the ocean, underground, and these breakouts continually increase the vertical thickness and lateral extent of the whole lava flow. 

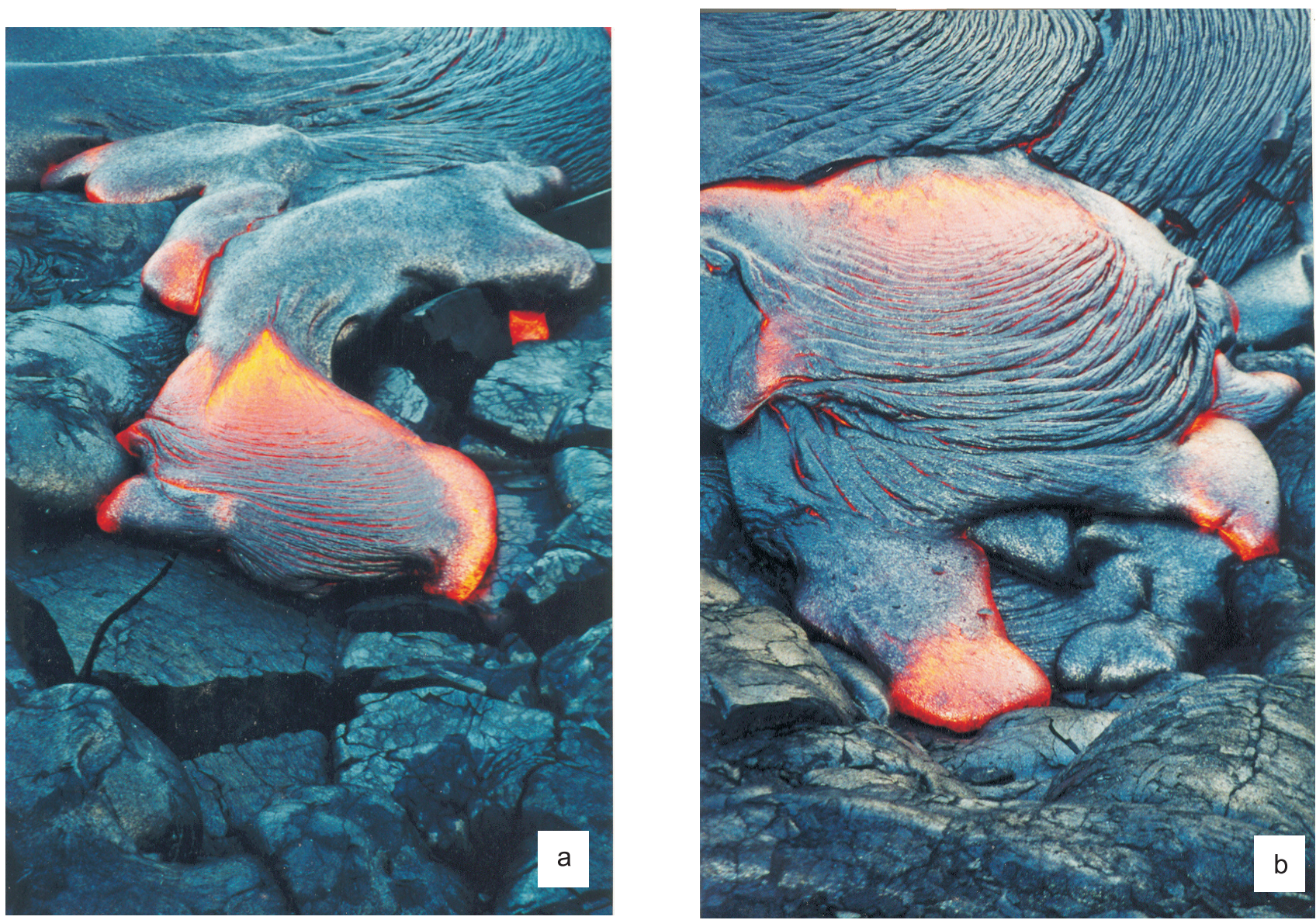

Figure 2. Snapshots of growing lava lobes on Kilauea volcano. Photos by HCS, May 2002. (a) A fresh, 0.5-metre-wide pahoehoe lava lobe that is only a few seconds old. Note how the colour of the lava progressively changes along the lobe's length. The front has come to rest and cooled sufficiently to look dark grey, while completely liquid lava (yellow to orange) is following at the rear. Ropes have begun to develop in the frontal part and will be propagated within seconds to the rear portions of the lobe. Note also the yellow lava oozing out of the sides of this lobe, to both right and left. The lobe swelled for a while before bursting along the sides. New lobes will have formed in less than a minute. This is how many of the huge Deccan Trap lava flows of India may have been emplaced - nice and slow. (b) Another, similar small active lobe in close-up, nicely showing the colour changes with cooling, ropes, and new breakouts forming.

Structures preserved in solidified lava indicate the nature of flow (turbulent or laminar), which depends on the viscosity of the lava. Lava flowing rapidly on steep slopes tends to break up and form viscous $a a$. Viscosity is inversely proportional to temperature and directly proportional to silica content. Kilauea (and in general, Hawaiian) lavas are basalts erupted at $\sim 1200^{\circ} \mathrm{C}$ and are rather fluid. 'Ropy' structures are very characteristic of the upper surfaces of individual lobes of the more fluid basalt lavas in Hawaii. The forms on these surfaces resemble cords or ropes, and the appearance is similar to the wrinkled surface of an elephant's trunk (figure 2). The Hawaiian word for this type of lava is pahoehoe. Ropy structure is not found in aa flows. Ropy structure begins to form at the front of a newly emplaced pahoehoe lobe as it comes to rest. The frontal part stops moving, but as new lava is being supplied at the rear end of the lobe, it crumples the cooler viscoelastic skin of the lobe into folds. Besides, these ropes get pulled outward by the lava moving beneath, but because the velocity of the lava is maximum along the central part of an elongated lobe, and least along its margins, the ropes on the skin become convex outward. If eventually the lava cannot be held by the lobe whose frontal part is chilled and at rest, the lobe bursts, and new lobes form. The lava shows shades of yellow to orange immediately as it comes out of a crack in the crust of a lava tube, or a previously emplaced lobe, and turns dull orange and then red and finally dark gray as it solidifies. For small lobes which cool quickly, this colour change takes only a few tens of seconds. The lobes develop laterally, and pile up above each other, and the lava flow as a whole enlarges its length, width and thickness (figure 3). For old lavas, convex ropes preserved in pahoehoe lobes are a useful flow direction indicator, but it is hazardous to extrapolate from a few exposed lobes to the entire lava flow. In a 

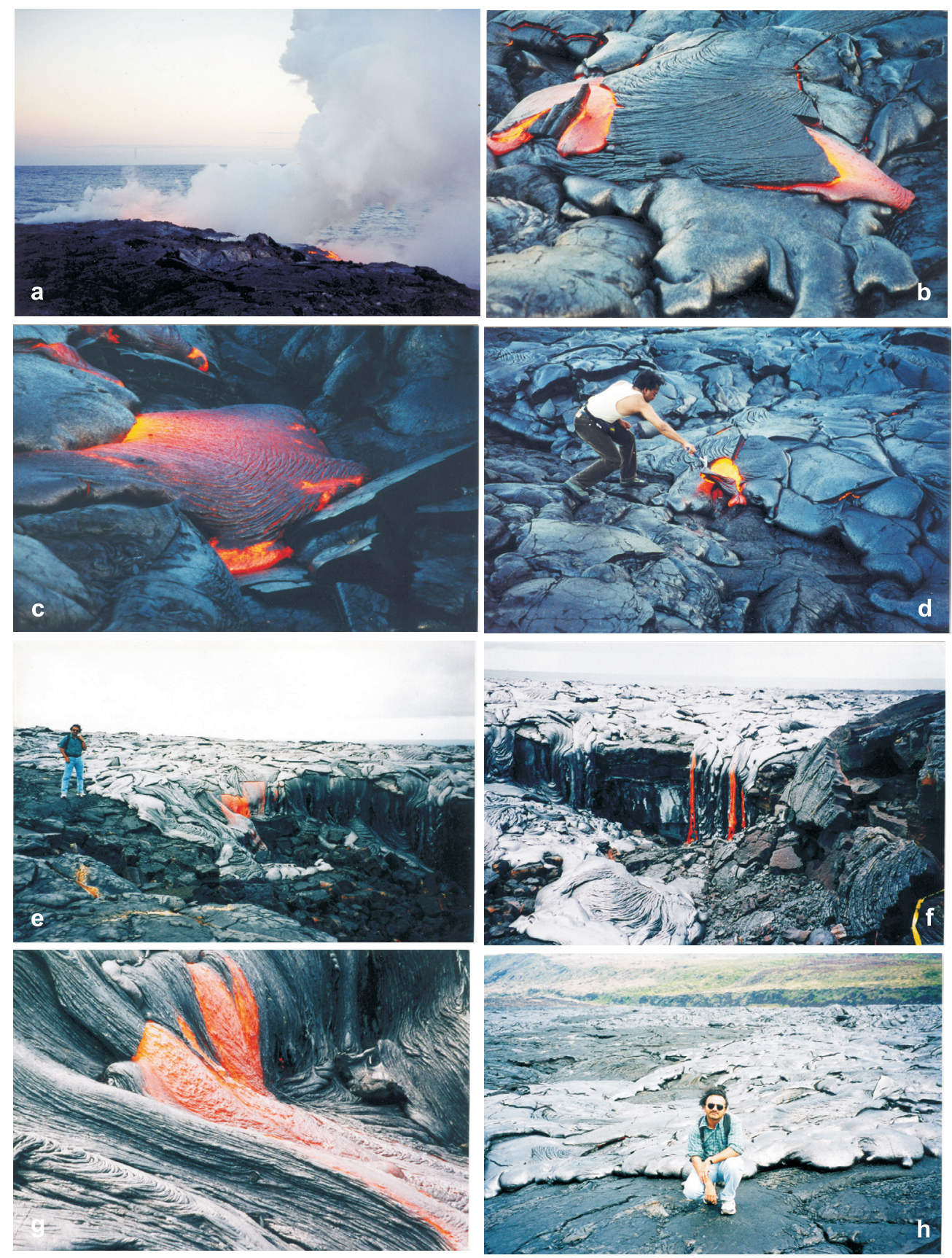

Figure 3. Snapshots of active lava flows erupted from the Pu'u' O'o' vent on Kilauea volcano, taken near the ocean entry. (a) Lava entering the ocean. Streams of yellow-hot lava are seen in the lower right distance, about $100 \mathrm{~m}$ away. Note the huge steam plume due to the heat of the lava, and the Pacific Ocean in the background. Sulphur dioxide $\left(\mathrm{SO}_{2}\right)$ and other toxic gases contained in the lava mix with the water, forming sulphuric acid and other chemicals. March 2002. (b) Breakouts from the right and left of a lobe with a ropy crust. Width of the lobe is $\sim 2 \mathrm{~m}$. May 2002. (c) Another active pahoehoe lava lobe only $2 \mathrm{~m}$ away, flowing toward the right, with ropy structure developing nicely. Note the newer, small breakout lobe or toe emerging from the base of this lobe towards the camera. May 2002. (d) It is not for nothing that Kilauea has the reputation of being the safest volcano on Earth. Here, HCS breaks open the solidified crust over an active lava flow with a rock hammer, exposing yellow-hot lava $\left(1200^{\circ} \mathrm{C}\right)$ within, which will pour out and cool in turn. Note the architecture of the flow and the small sizes of the individual lobes. May 2002. (e) to (h) Activity about $200 \mathrm{~m}$ inland of the ocean, July 2002. In (e) lava emerges through the roof of an underlying crusted-over lava tube and flows into a pit, as HCS looks on. Each lava 'spring' is $\sim 0.5 \mathrm{~m}$ wide. Note the ropes in some of the lobes that formed only a few minutes ago, and the compound character and the flatness of the sheet flow itself. (f) Lava streams emerge through the roof of a lava tube, only to fall into the pit. Each stream is $\sim 0.5 \mathrm{~m}$ wide. With decreased velocity and lava volume, the activity would resemble hot wax dripping from a candle (see Sheth 2003). (g) Close-up of the lava springs, each $\sim 0.5 \mathrm{~m}$ wide. Note how convex-outward ropes are forming in the one to the right. (h) Only $\sim 20 \mathrm{~m}$ from this pit, HCS poses in front of small lobes and toes emplaced only a few minutes ago. These are not frozen, but inflating, deforming and moving very slowly at the moment, and small chips are spalling off them producing a crackling sound. View is roughly due north. The steep face in the distance is a normal fault. Photos (a), (b), (c), (f), (g) by HCS; (d) by Jyotiranjan Ray; (e) and (h) by Vijay Sheth. 
single pahoehoe lava flow there can be thousands of individual lobes, and these can have their individual flow directions at any angle (even $180^{\circ}$ ) to the direction of progression of the lava flow as a whole. Thus the lava flow direction inferred from an individual lobe is always purely local.

While breakouts are happening, remember that a lot more lava is continuously flowing under the surface. Most large lava flows are able to spread far and wide not by surface flow, but by flow in a network of large tubes underneath a cooled crust (Cashman et al 1998; Keszthelyi and Self 1998; Kauahikaua et al 1998). This enables the lava to lose very little heat as it travels away from the vent. Some long lava flows in the western USA are known to have lost so little heat during insulated transport that they covered distances of several hundred kilometres from their eruptive vents before solidifying (Self et al 1997). If lava is continually being supplied to a lobe though slowly, the outer cooled crust slowly lifts up, the lobes swell over hours to days, and may coalesce into larger units (Hon et al 1994). This is known as 'inflation'. Old inflated lava lobes can be recognized through their characteristic internal structure, which consists of an upper and a lower crust separated by a thicker core zone, and the arrangement of vesicles. Vesicles are seen arranged both as vertical cylinders, which form as dissolved gases in the liquid rise upward due to their buoyancy, and as horizontal rows, formed as the rising gases encounter the overlying cold crust and turn horizontally under this mechanical barrier. The reader is referred to Self et al (1997) for a detailed description of this process, but features related to inflation, such as lava lobes with the characteristic structures, tumuli and squeeze-ups (figure 4), have been extensively described from the Deccan (e.g., Bondre et al 2000, 2004a, b; Duraiswami et al 2001, 2002, 2003).

\section{The compound flows of the Deccan Traps}

The $\sim 65$ million-year-old Deccan 'large basaltic province' (LBP, Sheth 2006; figure 5) is most spectacularly exposed in the Western Ghats (Sahyadri) range beside the western Indian rifted margin, and has been intensely studied for stratigraphy and geochemistry, the stratigraphic thickness here reaching $3 \mathrm{~km}$. This sequence has been divided into various formations and constituent members and flows, based on field criteria, geochemistry, and magnetic polarity. Despite considerable advances made in the chemical characterization of the Deccan Trap lava flows, systematic morphological studies and mapping of these huge lava flows have barely begun, yet there is growing interest in these (e.g., Sengupta and Ray 2006). The lower half of the Western Ghats stratigraphy, and about half of the total $\left(500,000 \mathrm{~km}^{2}\right)$ presentday areal extent of the province (figure 5), is made up almost wholly of 'compound' flows, i.e., flows made up of many subequal-sized lobes or flow units (Walker 1971; Keszthelyi et al 1999; Sheth 2003; Bondre et al 2004a, b). Many such large compound flows or flow fields, traceable over distances of $100 \mathrm{~km}$ or more, and $100 \mathrm{~m}$ or so thick, have volumes $\geq 1000 \mathrm{~km}^{3}$, and comprise thousands of individual flow units. Interestingly, these flows have a morphology and internal structures (e.g., ropy structures, tumuli) very much like those of the Hawaiian lavas (figure 4; e.g., Duraiswami et al 2001, 2002; Bondre et al $2004 a, b)$. This means that observations of modern Hawaiian lava flows can be usefully applied in the understanding of the eruption mechanisms of the much older Deccan lava flows. The Deccan certainly shares many features with active volcanic regions such as Hawaii and Iceland (this study; Sheth 2003; Sheth et al 2004), and other continental flood basalts (Jerram 2002; Waichel et al 2006).

Figure 6(a) shows a sketch by Walker (1971) of a compound flow he examined at the Mula dam site, north of Ahmednagar. It is clear that the flow unit size is the same as that of active Kilauea flows (see figures 2-4; many more photos available from HCS). Figures 6(b) and 6(c) show sketches of compound pahoehoe flows, with similar small flow units, in the Sangamner area in the Deccan (Bondre et al 2004a). Figure 6(d) shows a compound flow with much larger flow units in the Sangamner area, in which a clear evidence for inflation was observed (Bondre et al 2000). Figure 6(e) shows a section in the Trimbak area mapped by Walker (1971), exposing tens of flow units over tens of metres. Most of these Deccan compound flows are internally very complex, made up of many small units $(\sim 1 \mathrm{~m}$ or less to a few metres thick at most) and toes (tens of $\mathrm{cm}$ thick). Again, field work in the Dhule region (figure 5) on a large, petrographically uniform (plagioclasephyric), apparently single compound flow at least $10,000 \mathrm{~km}^{2}$ in area and $\sim 100 \mathrm{~m}$ thick, shows the same small flow unit sizes and similar emplacement. In contrast to the Columbia River basalts, porphyritic textures are very common in the Deccan Trap lava flows, particularly the compound flows (Deshmukh 1988; Mahoney 1988). Such lavas may have had significant yield strength on account of phenocryst enrichment and may have been emplaced very slowly, though groundmass crystallinity is also important in deciding yield strength and flow rate (Cashman et al 1999). The possibility that the abundant plagioclase phenocrysts (and 

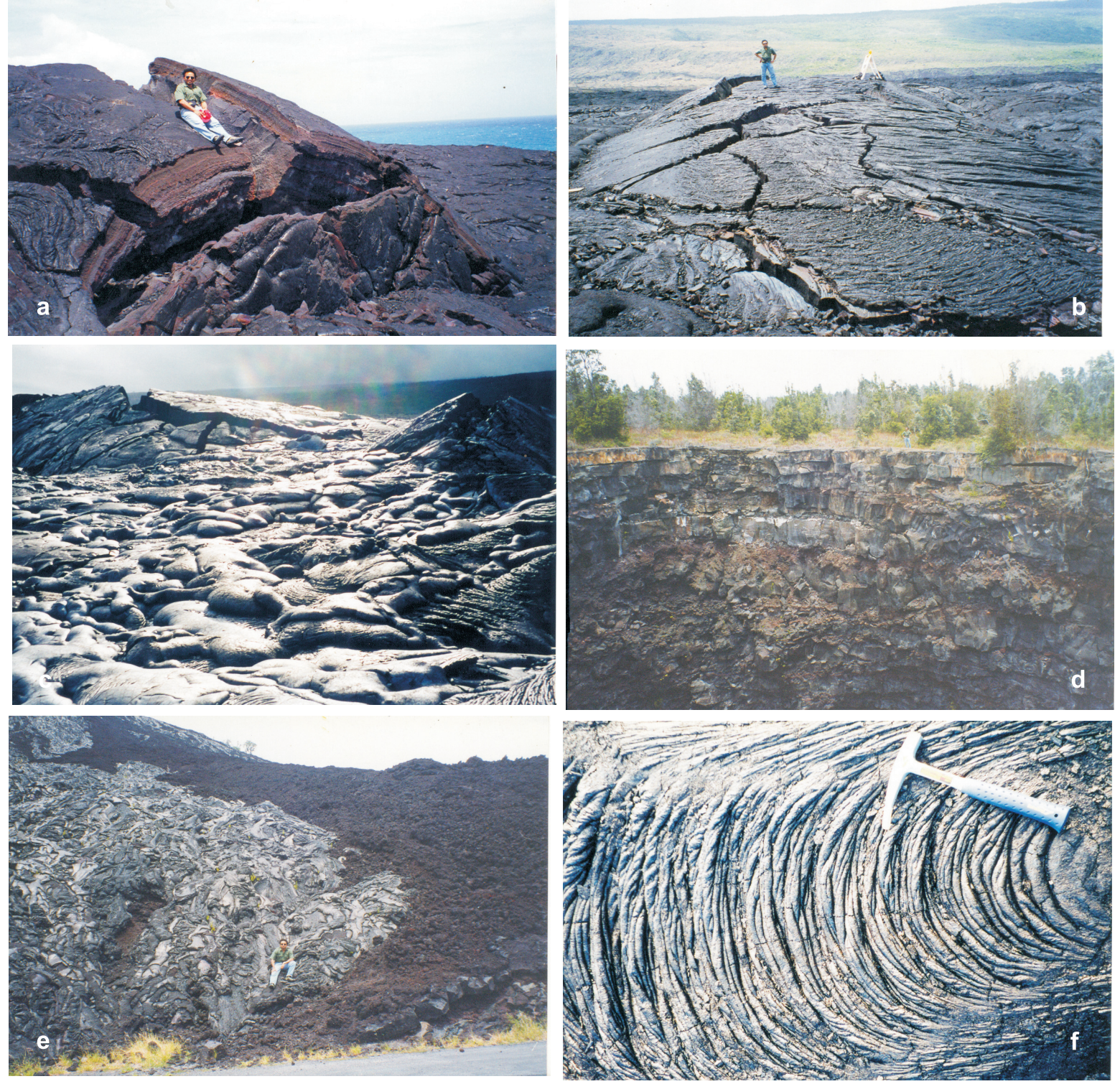

Figure 4. Features of recent, no longer active, compound pahoehoe flows on Kilauea, near the ocean entry. Lavas are from both Pu'u' O'o' vent and the Mauna Ulu vent, active 1969-74. (a) HCS on a large, prominent tumulus with an axial cleft. (b) HCS stands on another large, broad and low ('whaleback') tumulus with characteristic fissures on its top surface. (c) Typical appearance of a Kilauea pahoehoe flow. Note the complex compound nature, and the general flatness broken by the two tumuli, one to the left and another on the right. The sizes of these tumuli are similar to the ones in (a) and (b) above. (d) A section through compound lava flows exposed in the walls of a pit crater on Kilauea. The individual flow units here are somewhat larger than in the previous photographs. (e) Pahoehoe (entrail pahoehoe, silvery grey) and $a a$ (black, clinkery) in close juxtaposition, with HCS for scale. Both are distinctly different in their morphology, and yet both are part of the same eruption and the same lava flow (1972 Mauna Ulu lavas, locality Alanui Kahiko). The practice followed by some past workers in the Deccan, of identifying and demarcating different lava packages on the basis of their pahoehoe or $a$ a morphology, is basically flawed. (f) Ropy structure preserved on the top surface of a pahoehoe lobe. The lobe flowed from right to left. Hammer is $32 \mathrm{~cm}$ long. Photos (a), (b), (d), (e) by Stephen Self, August 2000; photos (c) and (f) by HCS, March 2002.

relatively less common olivine and clinopyroxene phenocrysts) in the lava flows may have grown after emplacement is real, but the observations indicate otherwise. Deshmukh (1988) described petrographic variations in the Deccan compound lavas, and described cases where substantial petrographic heterogeneity is seen between lobes, explaining this with the filtering of liquid leaving phenocrysts behind, settling of phenocrysts, etc. Thus, the lavas already carried phenocrysts in suspension at eruption. Two large dykes at Dediapada (Sheth et al, work in progress) are loaded with large $(4-5 \mathrm{~cm})$ plagioclase phenocrysts, which also indicate crystallization of phenocrystic plagioclase at depth. 


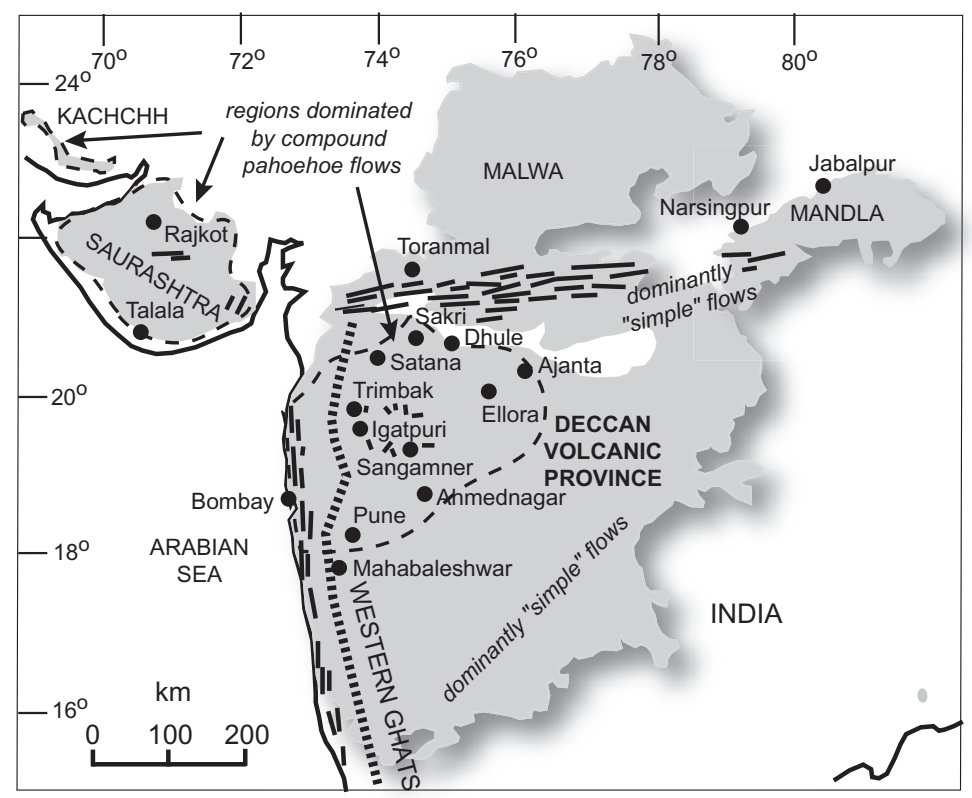

Figure 5. Sketch-map of the Deccan flood basalt province showing the localities mentioned in the text, the regions dominated by compound pahoehoe and simple flows, and the main dyke swarms (thick lines). Based on Bondre et al (2004a, b, 2006).

Walker (1971) commented on the prolific development of the compound pahoehoe flows in the Deccan (figure $7 \mathrm{a}-\mathrm{g}$ ), and wrote that the Ajanta caves in the central Deccan, famous for their religious sculptures and monuments carved in basalt, ought also to be famous for the magnificent compound flows themselves. The thick compound flows of the Bushe Formation exposed at Ajanta caves (Figure 7c-e) expose many individual units and lobes that are the same size as many flow lobes of the Kilauea. According to R. Duraiswami (pers. comm., 2006), the thicker of the lobes show the three-tier internal structure (upper crust-corelower crust) typical of inflated flow lobes, and also vesicle cylinders and horizontal vesicular zones, along with squeeze-ups. Bondre et al (2000) found well-developed inflation features in thicker flow units around Sangamner, though almost all compound flows that I have examined, in widely spaced localities (Dhule through Bombay, and much of Saurashtra, e.g., Talala and Rajkot, figure 5) have much smaller (Kilauea-size) flow units than the Sangamner ones (see figure 7). Thicker and larger flow lobes do exist in many areas, such as Pune, but in any given section, are much fewer in number as compared to the smaller lobes (N. Bondre, pers. comm., 2006). The local lava discharge rates for all these lava flows were therefore quite small, of the same order as for the recent and active Kilauea lava flows.

As Gregg and Keszthelyi (2004) point out, these low discharge rates inferred from the flow lobe sizes say nothing about the volume that was being erupted per unit time over the whole active flow front (the bulk eruption rate). The bulk eruption rate for the Deccan lavas must be obtained by integrating the lava volume along the whole flow front, usually several kilometres long, but as Gregg and Keszthelyi (2004) note, this is impossible for older flood basalts because of their inherent compound nature. It is not known, for example, what were the lengths of flow fronts of the Deccan compound flows that were active at any one time. A bulk eruption rate can be calculated in a direct or indirect manner as shown below, but whereas the first approach includes some practical difficulties, the second necessarily requires assumptions and analogy to other flood basalt eruptions.

\section{Deriving bulk eruption rates}

\subsection{Lava volume divided by eruptive duration}

The bulk eruption rate for flood basalts is in principle, directly determinable by dividing total erupted volume by eruptive duration, but in practice this is fraught with difficulties. Extremely high eruption rates and direct links to mass extinctions have been claimed for flood basalt provinces by workers claiming extremely short eruptive durations, but the methods and conclusions are highly variable.

For example, a Re-Os isochron age of $65.6 \pm$ $0.3 \mathrm{Ma}(2 \sigma)$ was presented by Allegre et al (1999) for Deccan basalts, based on which they argued 

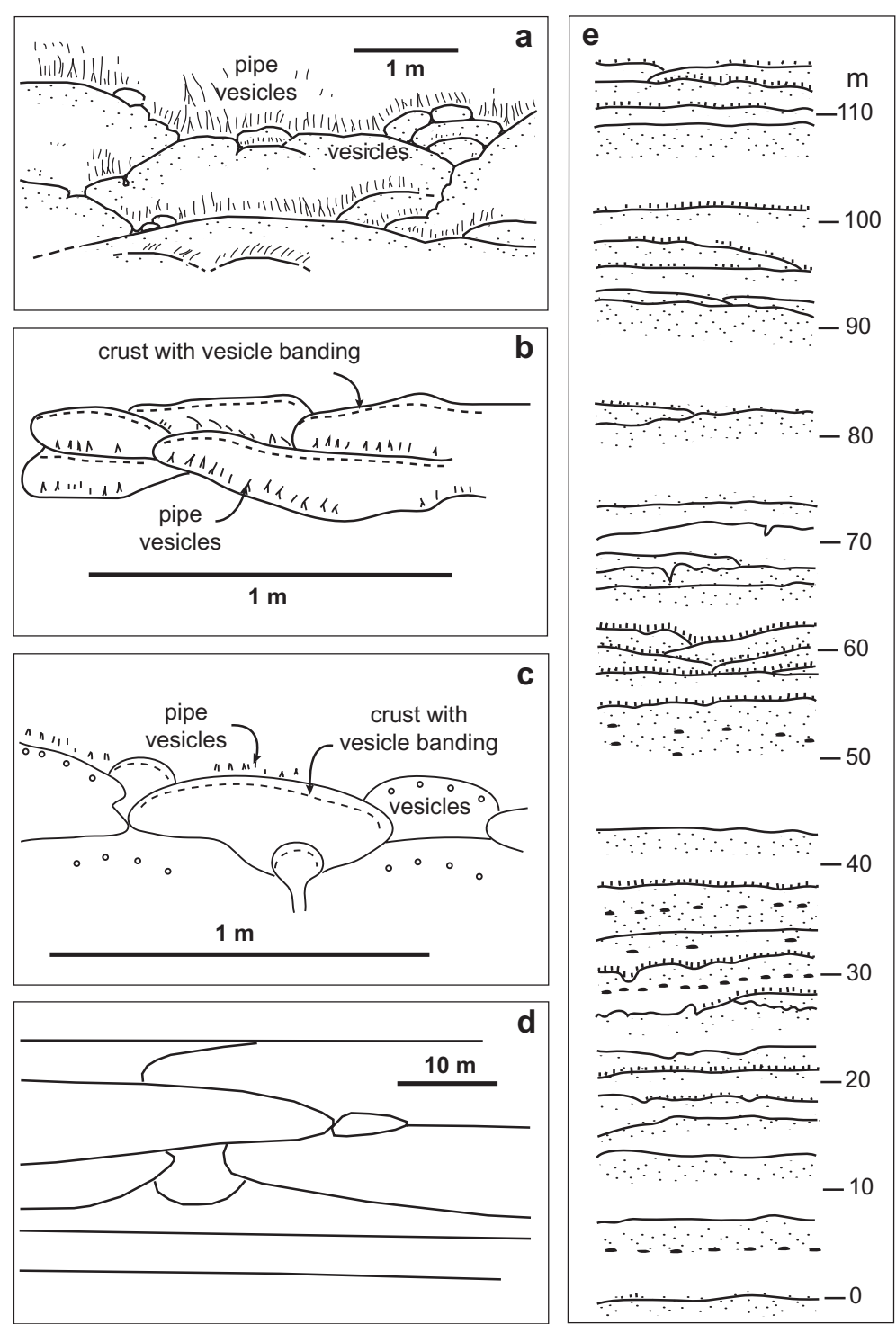

Figure 6. Sketches of outcrops and sections through compound pahoehoe flows in the Deccan province, based on Walker (1971) and Bondre et al (2004a).

for an extremely short (0.5 m.y.) eruptive duration exactly coincident with the $\mathrm{K}-\mathrm{T}$ boundary. The samples came from lavas with different petrogenetic histories, spread over an area a thousand $\mathrm{km}$ across and various stratigraphic levels, and so the isochron must be considered quite remarkable. The claimed isochron was shown by Baksi (2001) however to be an errorchron with an unacceptably high MSWD value of 22 , which value was not reported by Allegre et al (1999). Ar-Ar data are the subject of much dispute, with several workers arguing for a 0.5 m.y. eruptive duration for the thick Western Ghats sequence (e.g., Hofmann et al 2000) and others for a 4-5 m.y. duration (e.g., Venkatesan et al 1993; Pande 2002; Pande et al 2004), with Sheth et al $(2001 \mathrm{a}, \mathrm{b})$ reporting that the total duration of the volcanism, including late-stage basalts and felsic volcanics, was at least 8-9 m.y. Until this issue gets resolved it is not possible to directly calculate a bulk volumetric eruption rate for the Western Ghats lava pile, much less the entire province. Note that an average value for the bulk eruption rate obtained by dividing the total volume by total duration also cannot identify transient peaks or surges in the eruption rate separated by longer quiet intervals. Field evidence in the Deccan compound flow sections shows few and only small hiatuses between successive lavas in the Western Ghats, casting doubt on Pande's (2002) suggestion that the lavas cover up to six reversed polarity chrons, the in-between normal chrons not experiencing eruptions. Occasional red beds or boles are present, but again, some of them do not represent palaeosols but weathered pyroclastic horizons or altered glassy tachylite flows (Wilkins et al 1994; N. Bondre, pers. comm., 2006). 

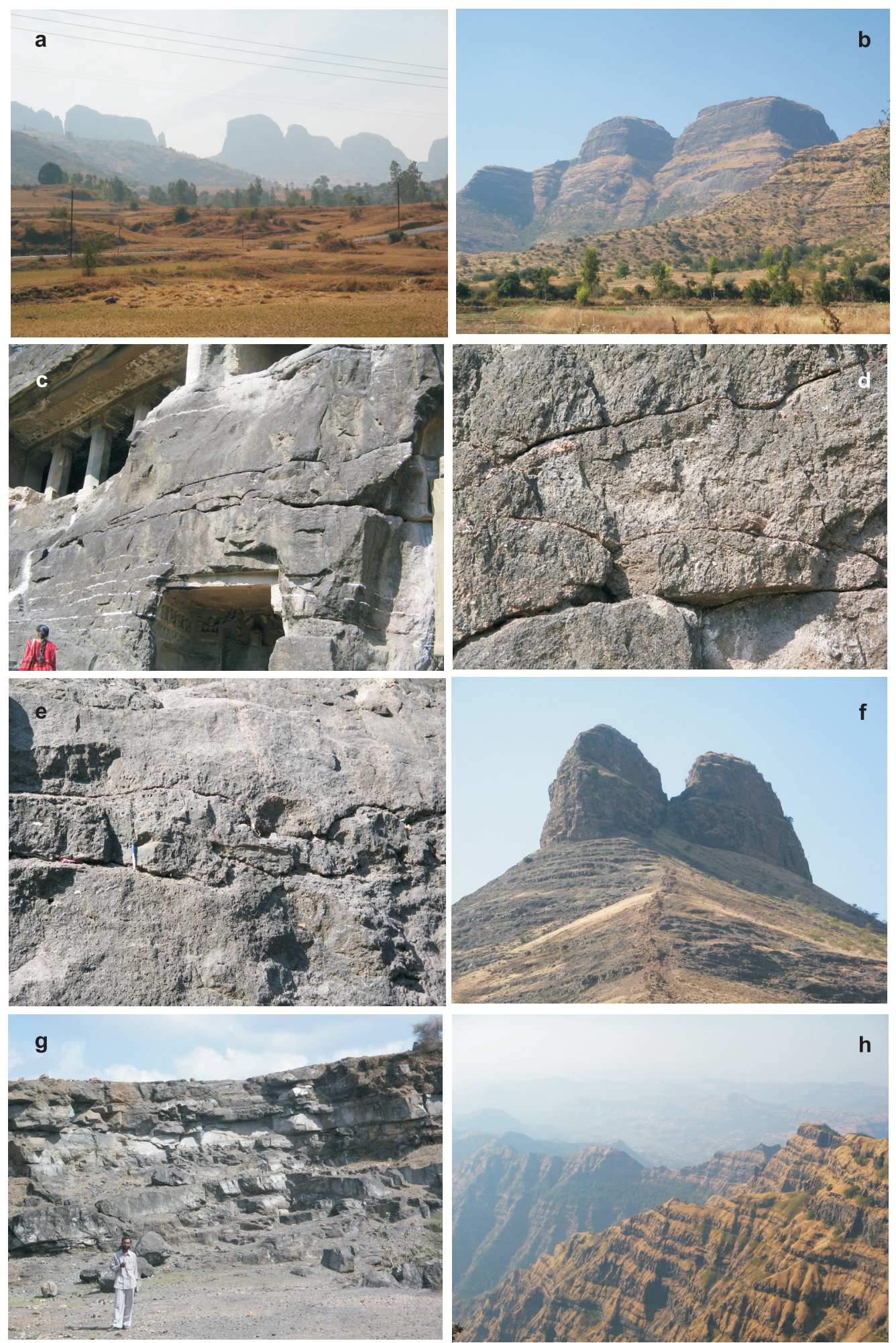

Figure 7. Some typical scenery developed on the Deccan compound lava flows, and morphology of the compound flows (see figure 5 for locations). All photos by HCS, December 2005 and June 2006. (a) Scenery around Trimbakeshwar (see figure 6e for a section sketch). Note the steep scarps with general rounded tops. (b) Scenery around Satana, central Deccan. Note again the scarps and rounded hills. (c) Flow lobes exposed in a vertical section at Ajanta caves. The lobe size is variable but small overall. Person for scale. (d) Several small lobes in close vertical and horizontal juxtaposition, Ajanta caves. Height of view is $1 \mathrm{~m}$. Compare to the sketches of the Deccan compound flows in figure 6 , and photos of Kilauea lava lobes in figures 2-4. (e) Similarly small lobes in juxtaposition. Pen near left-centre is $9 \mathrm{~cm}$ long. (f) A succession of flow lobes exposed on a lava butte near Bhamer village, north of Sakri. A dyke 3-4 m wide is seen cutting the lava flow. (g) Quarry near Talala, southern Saurashtra, exposing a compound lava flow. Compare the lobe sizes to the other examples. (h) View of the $>1$-km-thick ( $~ 300 \mathrm{~m}$ in the photograph) Mahabaleshwar sequence, dominated by 'simple' flows. Considerable thickness variation and lateral discontinuities are found when the flows are traced along strike, however. 


\subsection{Plagioclase growth rates and 'one-dimensional' eruption rate}

Sen (2001) suggested that the growth times of large (up to $5 \mathrm{~cm}$ ) plagioclase crystals found in the socalled 'giant plagioclase basalt' (GPB) flows found in the Deccan could be used in an indirect manner to calculate the eruptive duration and eruption rate for the lava pile. His premise was that the plagioclase formation times determined for the Makaopuhi lava lake in Hawaii could be more or less directly applied to plagioclase phenocrysts in the GPB flows. By noting that a 10-cm-long plagioclase crystal would take $3,200 \mathrm{yr}$ to form, Sen (2001) calculated the time period represented by six GPB flows in the Western Ghats stratigraphy to be $6 \times 3,200=19,200 \mathrm{yr}$. Then, assuming a thickness of $100 \mathrm{~m}$ of each GPB, and dividing the $600 \mathrm{~m}$ total thickness of the six GPBs by 19,200 yr, he derived a 'one-dimensional' eruption rate for the lava pile, of $0.031 \mathrm{~m} / \mathrm{yr}$. Ultimately, he divided the $1700 \mathrm{~m}$ thickness of the Western Ghats lava pile by this one-dimensional eruption rate and obtained an eruptive duration of only $\sim 55 \mathrm{kyr}$ for the entire Western Ghats lava pile, a figure one-tenth that proposed by even the most ardent rapid-volcanism proponents such as Hofmann et al (2000).

Sheth (2002), in a comment on Sen's (2001) approach, called reasonable Sen's (2001) starting premise that the Makaopuhi plagioclase growth times may be a guide to the GPB phenocryst plagiclases. But Sheth (2002) noted that eruption rate is lava volume emitted per unit time and a onedimensional eruption rate as calculated by Sen (2001) was meaningless. How is the thickness of a $G P B$ flow, measured in a vertical section through the lava pile, related to the time its plagioclase phenocrysts took to form in a magma chamber? In a reply, Sen (2002) agreed that eruption rate is typically expressed in terms of volume per time, but explained that the lack of knowledge of volumes of individual lava flows is what led him to derive and use a one-dimensional eruption rate.

Surprisingly, Sen et al (2006) have attempted to calculate indirectly, the formation time of the Western Ghats lava pile, based on the same flawed approach. From the theoretically estimated formation times of plagioclase crystals in GPB flows that separate the lower stratigraphic formations, they calculate the durations of time required to form the Jawhar and Igatpuri Formations as $\sim 1,500 \mathrm{yr}$. These formations are $\sim 225$ and $\sim 150 \mathrm{~m}$ thick, so, they argue, the one-dimensional eruption rates were 0.15 and $0.10 \mathrm{~m} / \mathrm{yr}$. Using these, they derive a new estimate of the formation time of the Western Ghats sequence as only $22.8 \mathrm{kyr}$. They cite the original paper by Sen (2001), but not the comment on it by Sheth (2002) which noted the unsound logic of the original calculation. Equally questionable is their assumption that every GPB flow, and all the lava flows in the formation which that GPB caps, represent eruptions from one magma chamber. Such a scenario is theoretically unlikely, and increasingly difficult to defend as data accumulate on dykes and probable feeder dykes in the province (Vanderkluysen et al 2004; Bondre et al 2006).

\subsection{A calculation based on analogy to other fissure eruptions}

Thordarson and Self (1998) and Self et al (1997) calculated an eruption rate of $4000 \mathrm{~m}^{3} / \mathrm{s}$ for the huge Roza Member of the Columbia River flood basalt province, using a total emplacement time of 10 years, and an exposed linear eruptive ventfissure system $150 \mathrm{~km}$ long. This rate is the same as the peak eruption rate of the 1783-84 Laki eruption in Iceland, the world's largest historic eruption that had severe environmental effects. As noted, large compound flows in the Deccan are $1000 \mathrm{~km}^{3}$, possibly much larger, though how much larger cannot be answered because of lack of systematic mapping of individual flow fields.

Two major oriented mafic dyke swarms are also recognized in the province, one trending ENEWSW along roughly the middle of the subcontinent and the other NNW-SSE along the western rifted margin, with a third important group of dykes along the Western Ghats (figure 5; Bondre et al 2006; Ray et al 2006). The largest known dyke in the province runs $\sim \mathrm{E}-\mathrm{W}$ just north of Dhule for $79 \mathrm{~km}$, and most other large dykes in the province, in this region, as also in central Saurashtra (figure 5), are $40-50 \mathrm{~km}$ long. These dykes are exposed today within vast compound lava flows made of thousands of Kilauea-type small flow units, and in all likelihood fed lava flows at higher levels, now lost to erosion. If so, and if the eruption rates for the lava flows were only of the order of $1 \mathrm{~m}^{3} / \mathrm{s}$ per metre of feeder dyke length (the typical Kilauea eruption rate, Self et al 1997), then a 5-km-long segment of a feeder dyke, active at any one time, would have erupted $5000 \mathrm{~m}^{3} / \mathrm{s}$ of lava, or $105 \mathrm{~km}^{3}$ over eight months (individual segments in the $27-\mathrm{km}$-long Laki fissure remained active one after the other over several months). Then eruptive activity could shift to another 5-kmlong segment by lateral magma migration, and thus the $50-\mathrm{km}$-long fissure would produce $1050 \mathrm{~km}^{3}$ of lava over 80 months, or 6.66 years (Ray et al 2006). This is quite comparable to the figures for the Columbia River basalts obtained by Self et al (1997) or Petcovic and Dufek (2005) and, notably, the total eruption rate involved per metre length of fissure $\left(1 \mathrm{~m}^{3} / \mathrm{s}\right)$ is no greater than that for modern Kilauea eruptions. It should be clear that the 
small size of the constituent flow units in the large Deccan compound flows is indicative of low local discharge rates, whereas the bulk eruption rates depend on the length of the active flow front, and these are difficult to know.

The above calculation is, of course, purely hypothetical (though realistic). Perhaps the bulk eruption rate for the Deccan, or at least the voluminous and thick Western Ghats sequence, will only be available once single flows or flow fields are systematically mapped, and the flows, flow fields or flow sequences dated at high resolution. The key point however is that the local discharge rates were small for the lower half of the entire Western Ghats stratigraphy, and over half the geographic area of the province, and these lavas were emplaced in a gentle, effusive, Kilauea-like fashion from regional fissures.

Note that I do not consider here the 'simple' flows of the province (figure $7 \mathrm{~h}$ ), many of which seem to run for several kilometres without any lateral discontinuities or terminations, i.e., no constituent flow units, and usually have prominent columnar jointing (e.g., Sengupta and Ray 2006). These flows, Bondre et al (2004a) remark, are unlike the simple Columbia River flows that Self et al (1997) find are merely very large and long lobes of pahoehoe flows that terminate against each other when followed a few kilometres. For example, Bondre et al (2004a) mention a simple lava flow near Pune that can be traced continuously for $80 \mathrm{~km}$ without any lateral variation in thickness. More recent work (N Bondre, unpubl. data, pers. comm., 2006) does show, however, pinching and swelling of the 'simple' flows along strike and laterally juxtaposed flow units, though the units themselves are very extensive and thick. Such flows may indeed have formed at high eruption rates. The Deccan, as other flood basalts, shows significant morphological differences in its constituent lava flows that demand significantly different emplacement mechanisms and thereby the likely environmental impacts. Comparative studies worldwide are essential, though any generalization (not only inter-province, but also intra-province) is dangerous.

\section{A note on some misconceptions in Deccan volcanology}

Whereas the growing interest in Deccan volcanology is a good sign, the enthusiast must beware the misconceptions and misinformation that abound in some previous Deccan volcanology literature. This literature is misinformed and misleading, the authors not having had direct experience of active volcanism or grasped the abundant literature by workers studying active volcano areas.

For example, some workers (e.g., Raja Rao 1984) have equated $a a$ flows to 'simple' flows, and pahoehoe flows have been equated by some to compound flows. But $a a$ and simple flows are very different things. The simple flows are thick, extensive sheets that are usually columnar-jointed (sometimes with multiple tiers) and maintain constant thickness over considerable distances. The $a a$ flows are clinkery and have thick cores, and are also usually compound like pahoehoe flows, though less commonly so than pahoehoe, as Walker (1971) noted decades ago. 'Simple' flows are not common on Kilauea and the older Hawaiian volcanoes, whereas $a a$ is very common on them, owing in part to steeper volcano slopes. Raja Rao (1984) also used the incomprehensible term 'simple pahoehoe'.

The $a a$ flows have rough surfaces, in contrast to the smooth pahoehoe flows. Consider a statement by Misra (2002, p. 117), however: "The compound (pahoehoe) flows are characterized by clinkery nature, baking and induration effects, ropy and bun-shaped structures, lava toes, squeeze ups...". Clinkery is precisely the word that is applied by workers to $a a$, not pahoehoe. In the same paper, Misra (2002) claimed a large number of lava channels and lava tubes in the Deccan based on field work and study of satellite images. Some of his examples of lava channels do strongly resemble active lava channels in Hawaii and he is in all probability correct about them, though his quoted widths of $300 \mathrm{~m}$ for the lava channels seem excessive. He also identified lava tubes as much as $100 \mathrm{~m}$ wide, from the sinuous distribution pattern of disconnected, residual hills of the basalts, as around Songir north of Dhule. This claim was questioned by Dole et al (2002), and by Duraiswami et al (2005) who provided detailed sketches of the morphology and internal structure of these lava flows. A possible lava tube was reported by Duraiswami et al (2004) from Daund, near Pune.

There have been claims that some of the lava flows in the Deccan province are not Deccan but Quaternary in age. Karmarkar et al (1993) noted volcanic ash beds of Quaternary age exposed near Pune and in the Narmada region of the Deccan province. The ash may well have been derived from halfway across the globe, rather than represent local activity. Karmarkar et al (1993) reported a Quaternary 'volcanic breccia' near Ahmednagar, the breccia following the slope carved out of the underlying Deccan lavas by a recent stream. Based on their descriptions and field sketches, the 'volcanic breccia' is probably a debris-slide or debrisflow deposit and that this follows the slope of the ground would not be surprising. They also reported field examples from other areas that in 
their opinion suggest recent volcanic activity. Thus, they reported lava flows and toes with ropes that appear to have emanated from cracks along the banks of streams, of recent age, and flowed towards or along the streambeds. As noted earlier in this paper, the direction of movement of a small lava lobe in a compound lava flow can be at any angle to the direction of movement of the lava flow as a whole, and ropes on a lava lobe give a flow direction that is purely local. In any case, the observations of Karmarkar et al (1993) can be explained well by exhumation-related relief. The lava lobes are not controlled by, or have flowed along, modern or recent streams; rather, the erosional exhumation is faithfully bringing out the original topography of the lava flow surfaces ( $\mathrm{N}$ Bondre, pers. comm., 2006). That this has happened in the Deccan is well seen in the examples of the tumuli-rich flows reported by Duraiswami et al (2001, 2002). Erosional exhumation has faithfully re-created the original hummocky surface morphology of these flows.

\section{A note on environmental impact}

A note is in order on the environmental/atmospheric effects of the Deccan volcanic episode. As Self et al (1997) note, though flood basalts emit large amounts of $\mathrm{CO}_{2}$ into the atmosphere, the quantities are small compared to the atmospheric $\mathrm{CO}_{2}$ inventory. On the other hand, flood basalt eruptions can have major climatic (and thereby biotic) impact if volcanic $\mathrm{SO}_{2}$ and $\mathrm{H}_{2} \mathrm{~S}$ can be pumped high enough into the atmosphere (stratospheric levels) to be transported as sulphur aerosols around the Earth.

Noting the major detrimental effects on the environment of the historic (1783-84) Laki fissure eruption in Iceland, Earth's largest historic eruption (Thordarson and Self 2003), it is no surprise that flood basalt provinces of the past have been suggested to have been directly instrumental in the mass extinctions (e.g., Self et al 2005). Such flood basalts comprise hundreds of eruptions vastly larger than the Laki eruption. For fissure eruptions, volcanic gases reach a height in the atmosphere controlled by the mass eruption rate per unit length of fissure, the volatile content of the magma, and the atmospheric moisture content. Importantly, the Laki eruption could wreak havoc on the environment because of the high latitude of Iceland, at which the tropopause is low $(10 \mathrm{~km})$, and therefore the eruption was able to inject gases into the stratosphere. The Deccan eruptions 65 m.y. ago occurred at $30^{\circ} \mathrm{S}$ latitude, over which the stratosphere would have been $\sim 14 \mathrm{~km}$ above the surface.

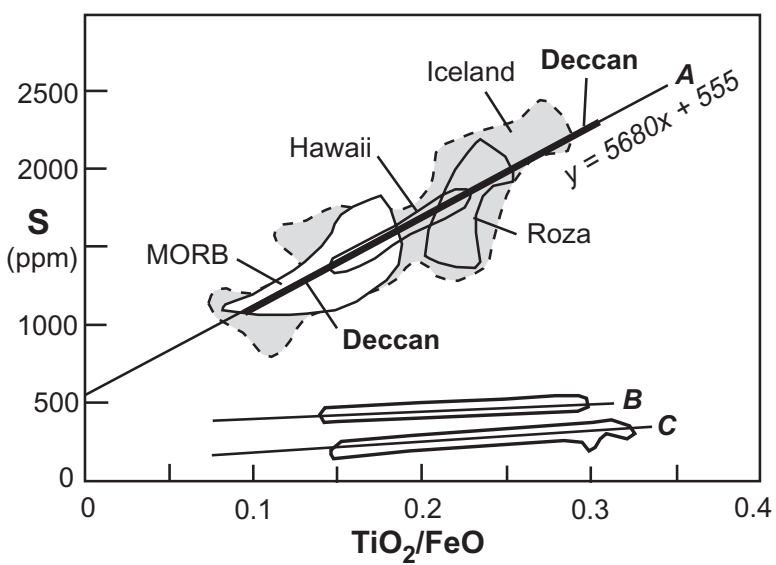

Figure 8. A plot of sulphur content (ppm) vs. the $\mathrm{TiO}_{2} / \mathrm{FeO}$ ratio for flood basalts, after Self et al (2005). The diagonal straight line $(A)$ is their best-fit line through the data fields of pre-degassing magmatic sulphur contents, though not quantified statistically by the authors. Note that no direct measurements of sulphur contents in the Deccan lavas or melt inclusions in phenocrysts exist. Therefore, the equation of this line was derived here by simply noting down coordinates of points along it, and based on this equation, the pre-degassing sulphur contents of the Deccan flood basalts (624 samples, Sheth 2005) were calculated (at 1,073 to $2,333 \mathrm{ppm}$ ) using their $\mathrm{TiO}_{2} / \mathrm{FeO}$ ratios. The tight correlation of the data (thick line) is thus purely artificial, but the line is merely intended to convey and compare the pre-magmatic sulphur contents of the other flood basalts with the calculated ones of the Deccan basalts. The field and line $B$ represent data on sulphur concentrations in tephra (after vent degassing) for the other flood basalts, and $C$ represents data obtained on lavas (after flow degassing).

The important question therefore is, what was the emplacement of the Deccan flood basalts like? The answer to this question can be found in the morphology and architecture of the Deccan lava pile itself. Clearly, much of the Deccan lava pile spread out on the surface at low eruption/discharge rates, which led to the formation of small flow units. Their biotic and atmospheric impact would depend, of course, on their eruption rate (volume emitted per unit of time), mode of emplacement (laminar vs. turbulent) and concentrations of volatile elements such as sulphur contained in them. For the latter, no direct measurements exist. However, Self et al (2005) suggest that the Deccan eruptions could have been a major detriment to the environment at that time. The use of the chemical ratio $\mathrm{TiO}_{2} / \mathrm{FeO}$ (advocated by Self et al 2005) to infer pre-magmatic sulphur contents for the Deccan flood basalts of the Western Ghats (624 samples, Sheth 2005) yields high values of 1,073 to $2,333 \mathrm{ppm}$ (figure 8). However, direct measurements on glassy selvages and phenocrysts are much preferable to such indirect means. Fresh glass is hard to find in the Deccan basalts, owing to widespread alteration through 
65 m.y., but measurements on melt inclusions in any unaltered phenocrysts will help to unambiguously establish the pre-degassing magmatic volatile contents of the Deccan magmas, and how much may have been released into the atmosphere by them.

Venkatesan et al (1993) and more recently Pande (2002) and Pande et al (2004) have been arguing that the lower part (notably dominated by the compound pahoehoe flows) of the 3-km-thick Western Ghats lava pile significantly preceded the $\mathrm{K}-\mathrm{T}$ extinctions. If so, this would be consistent with the morphology and emplacement mechanisms of the lavas. The extinctions were delayed until the emplacement of the compound flows was over, though these may have stressed the environment to a degree. It was then the Chixculub bolide impact in Yucatan, Mexico and the extensive 'simple' lava flows of the Deccan with high volumetric eruption rates, making up the upper stratigraphic levels of the Western Ghats and a large area of the Deccan province that had the catastrophic atmospheric-biotic effects.

\section{Conclusions}

The compound pahoehoe lava flows of the Deccan Traps, however large, would have formed in a very similar fashion to the modern-day Kilauea volcano lavas in Hawaii. Differences of opinion exist whether flood basalt lava flows of the past are simply enlarged analogues of modern inflated Hawaiian flows (see Self et al 1997; Anderson et al 1999), but this debate, as Bondre et al (2004a, b) rightly note, has been based largely on observations from and arguments for the Columbia River flood basalts as representatives of all flood basalts. Even for the Columbia River basalts, Reidel (1998) proposed that the inflation model of Self et al (1997) was valid for the flow margins, whereas the main portions of the flows were emplaced by fast laminar flow, not turbulent flow. It is clear that even individual provinces have a great variety of lava morphology and emplacement modes and any generalizations are dangerous. I point out that, while it may be debatable whether the large flood basalt flows are highly scaled-up versions of the inflated Hawaiian flows, the key point is that no scaling-up is necessary for all flood basalts. Field data require that the emplacement of the entire lower half of the Deccan flood basalts was no more catastrophic than the quiet, effusive Kilauea lava flows of today. The Kilauea lavas are thus direct analogues of half of the Deccan lavas, though the Columbia River flood basalts are quite different from both in morphology and emplacement.
Large $\left(\geq 1000 \mathrm{~km}^{3}\right)$ Deccan compound flows could have formed even at low local volumetric eruption rates identical with those of Kilauea, over time scales of only decades or less, from long $(40-50 \mathrm{~km})$ fissure systems, and observations of Kilauea's active lava flows can be usefully extended to these voluminous and extensive lavas. Systematic future volcanological studies of the older, sufficiently-well-preserved basaltic lava packages in older rock sequences of the Indian subcontinent (see references in Sheth and Pande 2004) e.g., the Malani province (Sharma 2004; Singh and Vallinayagam 2004), the Dongargarh sequence (Sensarma et al 2004), ophiolitic basalts in the Himalaya and the Andaman Islands (e.g., Srivastava et al 2004), as well as India's active volcano Barren Island in the Bay of Bengal (Alam et al 2004) should be of considerable interest.

\section{Acknowledgements}

I thank the University of Hawaii for the award of a SOEST Young Investigator (Assistant Researcher) position that enabled me to experience the magnificent volcanic geology and mesmerizing beauty of the Hawaiian islands during much of 200102 and during a previous visit in August 2000. Stephen Self, Watson Varricatt, Smitha Jose, Jyotiranjan Ray, Debabrata Banerjee, and Vijay and Daneshwari Sheth provided company, guidance and help on the Big Island and Kilauea on various occasions. I thank many colleagues and coworkers whose company I have had during field work in the Deccan over the years, and Stephen Reidel, Ninad Bondre, and Raymond Duraiswami for constructive reviews of the manuscript.

\section{References}

Alam M A, Chandrasekharam D, Vaselli O, Capaccioni B, Manetti P and Santo P B 2004 Petrology of the prehistoric lavas and dyke of the Barren Island, Andaman Sea, Indian Ocean; In: Magmatism in India through Time (eds) Sheth H C and Pande K ; Proc. Indian Acad. Sci. (Earth Planet. Sci.) 113 715-722.

Allegre C J, Birck J L, Capmas F and Courtillot V 1999 Age of the Deccan Traps using ${ }^{187}$ Re- ${ }^{187}$ Os systematics; Earth Planet. Sci. Lett. 170 199-204.

Anderson S W, Stofan E R, Smrekar S E, Guest J E and Wood W 1999 Pulsed inflation of pahoehoe lava flows: Implications for flood basalt emplacement; Earth Planet. Sci. Lett. 168 7-18.

Baksi A K 2001 Misuse of radiometric data: The critical role of simple statistical tests. Global Wrench Tectonics Workshop, Bergen (www.earthevolution.org)

Bondre N R, Duraiswami R A, Dole G, Phadnis V M and Kale V S 2000 Inflated pahoehoe lavas from the Sangamner area of the western Deccan volcanic province; Curr. Sci. 78 1004-1007. 
Bondre N R, Duraiswami R A and Dole G 2004a Morphology and emplacement of flows from the Deccan volcanic province, India; Bull. Volcanol. 66 29-45.

Bondre N R, Duraiswami R A and Dole G 2004b A brief comparison of lava flows from the Deccan volcanic province and the Columbia-Oregon Plateau flood basalts: Implications for models of flood basalt emplacement; In Magmatism in India through Time (eds) Sheth $\mathrm{H} \mathrm{C}$ and Pande K; Proc. Indian Acad. Sci. (Earth Planet. Sci.) 113 809-817.

Bondre N R, Hart W K and Sheth H C 2006 Geology and geochemistry of the Sangamner mafic dyke swarm, western Deccan volcanic province, India: Implications for regional stratigraphy; J. Geol. 114 155-170.

Cashman K, Pinkerton H and Stephenson J (eds) 1998 Introduction to special section: Long lava flows; J. Geophys. Res. 113 27,281-27,289.

Cashman K V, Thornber C and Kauahikaua J P 1999 Cooling and crystallization of lava in open channels, and the transition of pahoehoe lava to aa; Bull. Volcanol. 61 306-323.

Decker R and Decker B 2001 Volcanoes in America's National Parks. Airphoto Intl. Ltd., 256 pp.

Deshmukh S S 1988 Petrographic variations in the compound flows in Deccan Traps and their significance; In: Deccan Flood Basalts (ed) Subbarao K V; Mem. Geol. Soc. India 10 305-319.

Dole G, Bondre N, Duraiswami R A and Kale V S 2002 Discussion on 'Arterial system of lava tubes and channels within Deccan volcanics of western India' by Misra K S; J. Geol. Soc. India 60 597-599.

Duraiswami R A, Bondre N R, Dole G, Phadnis V M and Kale V S 2001 Tumuli and associated features from the western Deccan volcanic province, India; Bull. Volcanol. 63 435-442.

Duraiswami R A, Bondre N R, Dole G and Phadnis V M 2002 Morphology and structure of flow-lobe tumuli from the western Deccan volcanic province, India; J. Geol. Soc. India 60 57-65.

Duraiswami R A, Dole G and Bondre N R 2003 Slabby pahoehoe from the western Deccan volcanic province: Evidence for incipient pahoehoe-aa transitions; J. Volcanol. Geotherm. Res. 121 195-217.

Duraiswami R A, Bondre N R and Dole G 2004 Possible lava tube system in a hummocky lava flow at Daund, western Deccan volcanic province, India; In: Magmatism in India through Time (eds) Sheth H C and Pande K; Proc. Indian Acad. Sci. (Earth Planet. Sci.) 113 819-830.

Duraiswami R A, Bondre N R and Dole G 2005 The Songir structure: Inflated lava flow or tube? J. Geol. Soc. India $65357-365$.

Frey F A and Rhodes J M 1993 Intershield geochemical differences among Hawaiian volcanoes: Implications for source compositions, melting process and magma ascent paths; Phil. Trans. Roy. Soc. London $\mathbf{A 3 4 2}$ 121-136.

Gregg T K P and Keszthelyi L P 2004 The emplacement of pahoehoe toes: Field observations and comparison to laboratory simulations; Bull. Volcanol. 66 381-391.

Hazlett R W and Hyndman D W 1996 Roadside Geology of Hawaii; Mountain Press Publ. Co., Missoula, 304 pp.

Hofmann C, Feraud G and Courtillot V $2000{ }^{40} \mathrm{Ar} /{ }^{39} \mathrm{Ar}$ dating of mineral separates and whole rocks from the Western Ghats lava pile: Further constraints on duration and age of the Deccan Traps; Earth Planet. Sci. Lett. 180 $13-27$.

Hon K, Kauahikaua J, Denlinger R, Mackay K 1994 Emplacement and inflation of pahoehoe sheet flows: Observations and measurements of active lava flows on
Kilauea volcano, Hawaii; Geol. Soc. Amer. Bull. 106 351-370.

Jerram D A 2002 Volcanology and facies architecture of flood basalts. In: Volcanic Rifted Margins (eds) Menzies M A, Klemperer S L, Ebinger C J and Baker J; Geol. Soc. Amer. Spec. Pap. 362 121-135.

Karmarkar B M, Kulkarni S R, Marathe S S 1993 Quaternary volcanic activity in Deccan plateau; Curr. Sci. 64 923-925.

Kauahikaua J, Cashman C V, Mattox T N, Heliker C C, Hon K A, Mangan M T and Thornber C R 1998 Observations on basaltic lava streams in tubes from Kilauea volcano, island of Hawaii; J. Geophys. Res. 103 $27,303-27,323$.

Kerr A C 2005 Oceanic LIPs: The kiss of death; Elements $1289-292$.

Keszthelyi S and Self S 1998 Some physical requirements for the emplacement of long basaltic flows; J. Geophys. Res. $10327,447-27,464$.

Keszthelyi L, Self S and Thordarson Th 1999 Application of recent studies on the emplacement of basaltic lava flows to the Deccan Traps; In: Deccan Volcanic Province (ed.) Subbarao K V; Geol. Soc. India Memoir. 43 485-520.

McLean D M 1985 Deccan Traps mantle degassing in the terminal Cretaceous marine extinctions; Cret. Res. 6 235-259.

Macdonald G A, Abbott A T and Peterson F L 1983 Volcanoes in the Sea: The Geology of Hawaii. 2nd edn; University of Hawaii Press, Honolulu, 517 pp.

Mahoney J J 1988 Deccan Traps; In: Continental Flood Basalts (ed.) Macdougall J D; Kluwer Acad. Publ., Dordrecht, pp. 151-194.

Misra K S 2002 Arterial system of lava tubes and channels in Deccan volcanics of western India; J. Geol. Soc. India 59 115-124.

Pande K 2002 Age and duration of the Deccan Traps, India: A review of radiometric and palaeomagnetic constraints; Proc. Indian Acad. Sci. (Earth Planet. Sci.) 111 115-123.

Pande K, Pattanayak S K, Subbarao K V, Navaneethakrishnan P and Venkatesan T R $2004{ }^{40} \mathrm{Ar}-$ ${ }^{39} \mathrm{Ar}$ age of a lava flow from the Bhimashankar Formation, Giravli Ghat, Deccan Traps. In: Magmatism in India through Time (eds) Sheth $\mathrm{H} \mathrm{C}$ and Pande K; Proc. Indian Acad. Sci. (Earth Planet. Sci.) 113 755-758.

Petcovic H L and Dufek J D 2005 Modelling magma flow and cooling in dykes: Implications for emplacement of Columbia River flood basalts; J. Geophys. Res. 110 B10201:doi:10.1029/2004JB003432

Raja Rao C S 1984 The geological control for formation of laterite in western Maharashtra; In: Proc. Symp. on Deccan Trap and Bauxite (eds) Prasad B and Manjrekar B S; Geol. Surv. India Spec. Publ. 14 262-265.

Ray R, Sheth HC, Mallik J 2006 Structure and emplacement of the Nandurbar-Dhule mafic dyke swarm, Deccan Traps, and the tectonomagmatic evolution of flood basalts; Bull. Volcanol. (in press)

Reidel S P 1998 Emplacement of Columbia River flood basalt; J. Geophys. Res. 103 27,393-27,410.

Self S, Thordarson Th and Keszthelyi L 1997 Emplacement of continental flood basalt lava flows; In: Large Igneous Provinces: Continental, Oceanic, and Planetary Flood Volcanism (eds) Mahoney J J and Coffin M F; Am. Geophys. Union Geophys. Monogr. 100 381-410.

Self S, Thordarson Th and Widdowson M 2005 Gas fluxes from flood basalt eruptions; Elements 1 283-287.

Sen G 2001 Generation of Deccan Trap magmas; Proc. Indian Acad. Sci. (Earth Planet. Sci.) 110 409-431. 
Sen G 2002 Giant plagioclase basalts, eruption rate versus time: Response to Sheth's comments and some additional thoughts; Proc. Indian Acad. Sci. (Earth Planet. Sci.) 111 487-488.

Sen G, Borges M and Marsh B D 2006 A case for short duration of Deccan Trap eruption; Eos 87197.

Sengupta P and Ray A 2006 Primary volcanic structures from a type section of Deccan Trap flows around Narsingpur-Harrai-Amarwara, central India: Implications for cooling history; J. Earth Syst. Sci., 115 (this issue).

Sensarma S, Hoernes S and Mukhopadhyay D 2004 Relative contributions of crust and mantle to the origin of the Bijli Rhyolite in a Palaeoproterozoic bimodal volcanic sequence (Dongargarh Group), central India; In: Magmatism in India through Time (eds) Sheth $\mathrm{H} \mathrm{C}$ and Pande K; Proc. Indian Acad. Sci. (Earth Planet. Sci.) $113619-648$.

Sharma K K 2004 The Neoproterozoic Malani magmatism of the northwestern Indian shield: Implications for crustbuilding processes; In: Magmatism in India through Time (eds) Sheth H C and Pande K; Proc. Indian Acad. Sci. (Earth Planet. Sci.) 113 795-808.

Sheth H C 2002 Comments on 'Generation of Deccan Trap magmas' by Gautam Sen; Proc. Indian Acad. Sci. (Earth Planet. Sci.) 111 483-485.

Sheth H C 2003 The active lava flows of Kilauea volcano, Hawaii; Resonance (J. Sci. Edu.) 8 24-33.

Sheth H C 2005 Were the Deccan flood basalts derived in part from ancient oceanic crust within the Indian continental lithosphere? Gond. Res. 8 109-127.

Sheth H C 2006 'Large Igneous Provinces (LIPs)': Definition, recommended terminology, and a hierarchical classification; J. Volcanol. Geotherm. Res. (in press).

Sheth H C and Pande K (eds) 2004. In: Magmatism in India through Time; Proc. Indian Acad. Sci. (Earth Planet. Sci.) 113 517-838 (www.ias.ac.in/ epsci/contdec2004.html)

Sheth H C, Pande K and Bhutani R 2001a ${ }^{40} \mathrm{Ar}-{ }^{39}$ Ar ages of Bombay trachytes: Evidence for a Palaeocene phase of Deccan volcanism; Geophys. Res. Lett. 28 3513-3516.

Sheth H C, Pande K and Bhutani R 2001b ${ }^{40} \mathrm{Ar}^{39} \mathrm{Ar}$ dating of a national geological monument: The Gilbert Hill basalt, Bombay, Deccan Traps; Curr. Sci. 80 1437-1440.
Sheth H C, Mathew G, Pande K, Mallick S and Jena B 2004 Cones and craters on Mount Pavagadh, Deccan Traps: Rootless cones? In: Magmatism in India through Time (eds) Sheth H C and Pande K; Proc. Indian Acad. Sci. (Earth Planet. Sci.) $\mathbf{1 1 3} 831-838$.

Singh A K and Vallinayagam G 2004 Geochemistry and petrogenesis of anorogenic basic volcanic-plutonic rocks of the Kundal area, Malani igneous suite, Rajasthan, India; In: Magmatism in India through Time (eds) Sheth H C and Pande K; Proc. Indian Acad. Sci. (Earth Planet. Sci.) $113667-682$.

Srivastava R K, Chandra R and Shastry A 2004 HighTi type N-MORB parentage of basalts from the south Andaman ophiolite suite, India; In: Magmatism in India through Time (eds) Sheth H C and Pande K; Proc. Indian Acad. Sci. (Earth Planet. Sci.) 113 605-618.

TenBruggencate J 2000 Hawaii: Land of Volcanoes. Mutual Publ., 102 pp.

Thordarson Th and Self S 1998 The Roza Member, Columbia River Basalt Group: A gigantic pahoehoe lava flow field formed by endogenous processes? J. Geophys. Res. 103 27,411-27,445.

Thordarson Th and Self S 2003 Atmospheric and environmental effects of the 1783-84 Laki eruption: A review and reassessment; J. Geophys. Res. 108 (D1): 4011.

Vanderkluysen L, Mahoney J J, Hooper P R 2004 Implications for the emplacement of the Deccan Traps (India) from isotopic and elemental signatures of dykes; EOS, Trans AGU, Fall Meet. Suppl. 45 V51B-0561 (abstract).

Venkatesan T K, Pande K and Gopalan K 1993 Did Deccan volcanism pre-date the Cretaceous/Tertiary transition? Earth Planet. Sci. Lett. 119 181-189.

Walker G P L 1971 Compound and simple lava flows and flood basalts; In: Deccan Trap and Other Flood Eruptions, Part I (ed.) U Aswathanarayana; Bull. Volcanol. 35 579-590.

Waichel B L, de Lima E F, Lubachevsky R and Sommer C A 2006 Pahoehoe flows from the central Parana continental flood basalts; Bull. Volcanol. 176 599-610.

Wignall P B 2005 The link between large igneous province eruptions and mass extinctions; Elements 1 293-297.

Wilkins A, Subbarao K V, Ingram G and Walsh J N 1994 Weathering regimes within the Deccan basalts; In: Volcanism (ed.) Subbarao K V, Wiley, New Delhi, pp 217-232. 